\title{
Ringprofylakse effektivt mot svineinfluensa
}

\author{
Antiviral profylakse med oseltamivir \\ kombinert med isoleringstiltak ga \\ radikal reduksjon av svineinfluensa- \\ smitte i militærforlegninger.
}

Svineinfluensapandemien (virus H1N1) i 2009 forte til intens debatt om hvordan smitte kan begrenses. I juni 2009 var det fire H1N1-utbrudd i kaserner i Singapore. Antiviral profylakse med oseltamivir (Tamiflu) ble gitt til en utvidet krets $(\mathrm{n}=1100)$ av potensielle smitteksponerte, såkalt ringprofylakse. Kombinert med andre smitteverntiltak, som isolering av alle med infeksjonssymptomer, førte dette til at antall nye tilfeller per smittebærer falt fra 1,91 til 0,11 (1). Av totalt 82 smittede ble kun sju smittet etter intervensjonen. Alvorlige bivirkninger av oseltamivir ble ikke observert.

- Ringprofylakse kombinert med isolering av syke, kontaktbegrensninger og undersøkelse av eksponerte synes å ha hatt en oppsiktsvekkende sterk effekt, sier overlege Bjørn Iversen ved Folkehelseinstituttet. - Resultatene er ikke direkte overførbare til det åpne samfunn, hvor muligheten til effektiv symptomovervåking og isolering er helt andre enn i militærforlegninger. Likevel er det interessant at man under gitte betingelser kan oppnå en så markert effekt.

Studien styrker argumentene for å vurdere liknende tiltak helt i starten av nye epidemier, f.eks. ved første sykdomstilfelle i Norge. Hensikten er da å forsinke epidemien og vinne tid til vaksinering. Nokså raskt under en epidemi vil imidlertid denne type tiltak ha minimal effekt, fordi smittekildene er mange og ukontrollerbare. Det kan da være en pedagogisk utfordring å avvikle iverksatte forholdsregler, eksempelvis fortelle at familien til syke ikke lenger skal tilbys oseltamivirprofylakse, sier Iversen.

\section{Jon Amund Kyte \\ jon.amund.kyte@rr-research.no \\ Tidsskriftet}

\section{Litteratur}

1. Lee VJ, Yap J, Cook AR et al. Oseltamivir ring prophylaxis for containment of $2009 \mathrm{H} 1 \mathrm{~N} 1$ influenza outbreaks. N Engl J Med 2010; 362: 2166-74.

\section{Liten influensarisiko i fly}

Det er en lav, men målbar risiko for overføring av pandemisk influensa A (H1N1) på passasjerfly. Risikoen gjelder først og fremst dem som sitter i nærheten av passasjerer med symptomer. I en ny studie er denne avstanden beregnet til to flyseterekker (BMJ 2010; 340: c2424).

Studien omfattet 121 passasjerer som satt bakerst i en Boeing 747 som ankom til New Zealand 25.4. 2009. Data ble innsamlet retrospektivt via spørreskjema til alle passasjerer og PCR-unders økelse av dem med symptomer. Resultatene viser at influensa ikke er særlig smittsomt - heller ikke under flyreiser, ifølge en kommentar i Ugeskrift for Læger (2010; 172: 1962).

\section{Rask behandling - økt overlevelse}

Pasienter med ST-elevasjonsmyokardinfarkt (STEMI) bør få fibrinolysebehandling innen 30 minutter og $\mathrm{PCl}$-behandling innen 90 minutter. Hvis denne tidsgrensen ikke overholdes, fordobles mortaliteten. Det viser en ny kanadisk studie (JAMA 2010; 303: 2148-55).

Den omfattet 80 sykehus og ca. 6700 pasienter med akutt myokardinfarkt, hvorav 2300 hadde ST-elevasjonsmyokardinfarkt. Av disse ble 1800 behandlet med reperfusjon: $21 \%$ fikk fibrinolyse og $79 \%$ fikk primær $\mathrm{PCl}$-behandling.

$54 \%$ av pasientene fikk ikke fibrinolyse i tide, tilsvarende tall for $\mathrm{PCl}$-behandling $\operatorname{var} 68 \%$. De som ikke fikk behandling i tide, hadde økt risiko for død innen 30 dager: $6,6 \%$ versus $3,3 \%$ for dem som ble behandlet til riktig tid (OR 2,1).

\section{Lengre CMV-profylakse ved lungetransplantasjon}

\section{Forebyggende antiviral behandling i 12 måneder gir færre tilfeller av cytomegalovirusinfeksjon etter lungetransplantasjon.}

Infeksjon med cytomegalovirus (CMV) er vanlig etter lungetransplantasjon, og ved flere transplantasjonssentre får pasientene forebyggende antiviral behandling i 1-3 måneder.

I en amerikansk multisenterstudie ble lungetransplanterte som hadde fătt tre måneders behandling med valganciklovir randomisert til enten forlenget behandling $(n=70)$ eller placebo $(n=66)$ i ni måneder (1). Cytomegalovirusinfeksjon oppsto hos $4 \%$ og $32 \%$ i de to gruppene ( $p<0,001$ ). Tilsvarende forskjeller ble påvist for grad av infeksjon. Andelen pasienter med rejeksjonstegn, opportunistiske infeksjoner, bivirkninger, resistensmutasjoner og avvikende blodprøveresultater var lik. Forekomsten av cytomegalovirusinfeksjon i de neste seks månedene var lav i begge gruppene.

- Cytomegalovirusinfeksjon etter organtransplantasjon kan gi viremi, pneumonitt, gastroenteritt og flere andre sykdommer, foruten økt risiko for avstøtning av transplantatet, sier seksjonsoverlege Øystein

Bjørtuft ved Lungemedisinsk avdeling, Oslo universitetssykehus, Rikshospitalet.

- De siste årene har alle lunge-

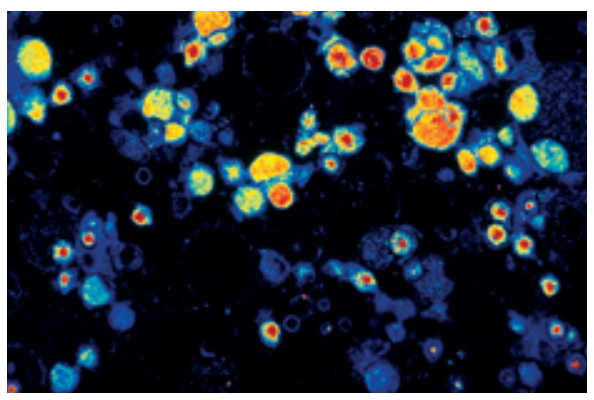

Transmisjonselektronmikroskopisk bilde av cytomegalovirus. Illustrasjonsfoto ( Scott Camazine/ Photo Researchers/GV-Press/NordicPhotos

transplanterte hos oss fått antiviral CMVprofylakse i tre måneder, og ved ulik CMVstatus mellom mottaker og giver i ytterligere seks måneder, forteller Bjørtuft. - Erfaringene er gode. Denne studien tyder på at profylaktisk CMV-behandling med fordel kan gis i 12 måneder, men kostnadene med en slik strategi er ikke vurdert, sier han.

\section{Petter Gjersvik}

petjense@online.no

Tidsskriftet

\footnotetext{
Litteratur

1. Palmer SM, Limaye AP, Banks M et al. Extended valganciclovir prophylaxis to prevent cytomegalovirus after lung transplantation. A randomized, controlled trial. Ann Intern Med 2010; 152: 761 -9.
} 